\title{
Hevostallien pelastussuunnitelma
}

\author{
Milka Taivassalo $^{1)}$, Katriina Lehtimäki ${ }^{2)}$, Olli Kangas ${ }^{2)}$, Pirjo Suhonen $^{2)}$, Arja Aalto ${ }^{3)}$ \\ 1)Iisalmi,milemachine@hotmail.com \\ ${ }^{2)}$ Savonia-ammattikorkeakoulu, Iisalmi,etunimi.sukunimi@savonia.fi \\ 3)Ylä-Savon ammattiopisto,Kiuruvesi, arja.aalto@ysao.fi
}

Tallilla toimivan työnantajan velvollisuus on laatia turvallisuusohjeet, jotka takaavat työntekijän turvallisuuden, terveyden ja hyvinvoinnin. Työntekijän puolestaan on noudatettava annettuja ohjeita ja huomioitava muita riskitekijöitä ja ilmoittaa, jos jossain ilmenee puutteita.

Tämän työn tarkoituksena oli laatia suurille hevostiloille ja talleille soveltuva ja tallien tarpeita palveleva pelastussuunnitelma. Pelastussuunnitelma on turvallisuusasiakirja, jonka tulee löytyä jokaiselta suurehkolta maatilalta. Pelastussuunnitelman tekoon velvoittavat Suomen pelastuslaki (468/03 8 ja 9 §) sekä pelastusasetus (787/03 $9 \S$ ja $10 \S)$. Suomen Kuluttajavirasto vaatii, että palveluntarjoajilla, esim. ratsastustalleilla, tulee olla myös ajan tasalla oleva turvallisuussuunnitelma. Nämä kaksi asiakirjaa voidaan yhdistää yhdeksi pelastussuunnitelmaksi. Sen voi tehdä itse, mutta se pitää hyväksyttää pelastusviranomaisella ennen käyttöönottoa.

Tässä työssä pelastussuunnitelman laadinta toteutettiin case-tutkimuksena kokoluokaltaan suurelle, yli 50 hevosen tilalle; Ylä-Savon ammattiopiston Hingunniemen opetumaatilalle. Pelastussuunnitelmaa varten henkilökunnalle ja opiskelijoille suunniteltiin ja järjestettiin alkusammutuskoulutus ja pelastusharjoitus yhteistyössä palo- ja pelastusviranomaisten kanssa. Turvallisuuskoulutukset antoivat tarvittavaa tietoa siitä, kuinka talleilla toimitaan tulipalossa.

Tämän työn tuloksena tuotettu pelastussuunnitelma lisää toiminnan turvallisuutta ja ohjaa turvallisiin menettelytapoihin mahdollisissa kriisitilanteissa. Tuotetussa pelastussuunnitelmassa keskitytään tallirakennusten turvallisuuteen. Suunnitelma sisältää riskianalyysin ja mm. tallirakennusten tiedot sekä tiedot turvallisista rakenneratkaisuista. Lisäksi suunnitelmassa on ohjeet siitä, kuinka toimia onnettomuustilanteissa ja ennaltaehkäistä onnettomuuksia ja vaaratilanteita: henkilökunnan tehtävät, ohjeet hevosten pelastamisesta ja tallien pohjapiirustukset poistumisreitteineen. Paloviranomainen on tarkastanut pelastussuunnitelman luotettavuuden. Talliyrittäjät voivat hyödyntää tehtyä suunnitelmaa taustatietoineen laatiessaan pelastus- tai turvallisuussuunnitelmaa talleilleen.

Asiasanat:

pelastussuunnitelma, turvallisuussuunnitelma, hevostallit, turvallisuus 


\section{Johdanto}

Suomen Pelastuslaki (468/03 8 ja 9 §) velvoittaa suuria maatiloja tekemään pelastussuunnitelman, ja Kuluttajavirasto edellyttää palveluntarjoajilta turvallisuussuunnitelman löytymistä. Tämän työn tarkoituksena oli tehdä hevostalleja palveleva pelastussuunnitelman pohja, jossa yhdistetään nämä molemmat turvallisuusasiakirjat.

Kuluttajaviraston mukaan turvallisuussuunnitelma tarvitaan, jos yrittäjä tarjoaa asiakaspalveluja, esim. valmennusta tai täysihoitoa. Pelastussuunnitelma puolestaan on pakollinen, jos maatilan toiminta on ympäristöluvanvaraista, se on kooltaan yli $1000 \mathrm{~m}^{2}$ tai jos siellä on yli 60 hevosta tai ponia. Hingunniemen opetusmaatila täyttää nämä määritelmät, joten molemmat turvallisuusasiakirjat löytyivät sieltä. Tallirakennuksissa oli kuitenkin tarve pelastussuunnitelmalle, joka keskittyisi turvallisuuteen nimenomaan hevosten ja niitä hoitavien henkilöiden näkökulmasta. Tässä työssä laadittiin siis pelastus- ja turvallisuussäädäkset ja -määräykset täyttävä sekä hevoset että niitä hoitavat henkilöt huomioon ottava pelastussuunnitelma.

Työ toteutettiin käytännössä case-tutkimuksena Ylä-Savon ammattiopiston Hingunniemen yksikössä Kiuruvedellä. Ammattioppilaitoksen opetusmaatila käsittää neljä eri tallirakennusta sekä maneesin, ja siellä on tilaa yli 60 hevoselle. Pelastussuunnitelman lisäksi kohdetilalla haluttiin järjestää turvallisuuskoulutusta ja testata suunnitelmien toimivuutta yhteistyössä paikallisten palo- ja pelastuviranomaisten kanssa.

\section{Aineisto ja menetelmät}

Taustatutkimuksessa perehdyttiin hevostalleja koskeviin turvallisuusmääräyksiin ja sääntöihin. Koska casetila oli Ylä-Savon ammattiopiston opetusmaatila, myös nuorten henkilöiden työntekoa koskevat määräykset on otettava huomioon. Pelastussuunnitelmaa laadittaessa on otettava huomioon seuraavat tallirakennusten ja työntekijöiden turvallisuuteen sekä hevosille suunnattuun maatilarakentamiseen liittyvät Suomen lainsäädännön lait ja asetukset:

- Pelastuslaki (468/2003)

- Maankäyttö- ja rakennuslaki (132/1999)

- Laki kulutustavaroiden ja kuluttajapalvelusten turvallisuudesta $(75 / 2004)$

- Työturvallisuuslaki (738/2002)

- Valtioneuvoston asetus työpaikkojen turvallisuus- ja terveysvaatimuksista (577/2003)

- Laki työsuojelun valvonnasta ja työpaikan työsuojeluyhteistoiminnasta (44/2006)

- Terveydensuojelulaki (763/1994)

- Työterveyshuoltolaki (1383/2001)

- Laki nuorista työntekijöistä (998/1993)

- Valtioneuvoston asetus nuorille työntekijöille erityisen haitallisista ja vaarallisista töistä $(475 / 2006)$

- Ammattitautiasetus (1347/1988)

Lakiselvityksen jälkeen verrattiin, kuinka pelastusasiakirjoihin kuuluvat asiat toteutuvat case-tilalla Hingunniemessä ja kuinka hyvin esimerkiksi opiskelijat on otettu huomioon. Hingunniemen opetusmaatilan tallin olosuhteisiin perehtyminen ja talliolosuhteiden havainnointi sekä henkilökunnan, erityisesti vastaavan tallimestari Arja Aallon, haastattelut olivat oleellinen osa koulutilan olojen selvittämistä. Havainnointi ja haastattelut tehtiin kesällä 2008 tekijän työelämäharjoittelun yhteydessä Hingunniemessä.

Työn pohjamateriaalina olivat jo olemassa olevat pelastus- ja turvallisuussuunnitelmat sekä pelastuslaitoksien erilaiset pelastussuunnitelmapohjat. Käytettävissä on ollut Kuluttajaviraston malleja turvallisuussuunnitelmista sekä lisäksi yksityisien tallien esimerkkejä niiden omista suunnitelmista. Niitä vertailemalla on luotu yhdistetyn turvallisuusasiakirjan sisältö. Käytännön kokemuksia ja -ideoita ja saatiin haastattelemalla Pohjois-Savon pelastuslaitoksen Kiuruveden paloaseman palomestari Tommi Antikaista. Palomestarin pitämät turvallisuusluennot sekä alkusammutusharjoitus antoivat toimijoille, niin opetusmaatilalla työskenteleville, siellä opiskeleville kuin pelastustehtävissä toimiville, tietoa palo-turvallisuudesta ylipäätään, mutta myös erittäin yksityiskohtaista tietoa Hingunniemen hevostallien turvallisuusnäkökohdista.

Pohjatietoja tallien pelastussuunnitelmaan kerättiin osittain koko Hingunniemen yksikön käsittävistä turvallisuus- ja pelastussuunnitelmasta. Koska edelliset suunnitelmat oli tehty jonkin aikaa sitten ja koska uuden suunnitelman tarkoituksena oli keskittyä nimenomaan tallirakennuksiin, kaikkea tietoa ei löytynyt ennestään painettuna mistään. Puuttuvat tiedot kerättiin henkilökuntaa haastattelemalla, tallirakennuksia 
tutkimalla ja pelastusviranomaisilta. Lopullinen pelastussuunnitelma, joka siis sisältää myös turvallisuussuunnitelmassa vaadittavat tiedot, on tarkistettu ja hyväksytetty Kiuruveden kaupungin pelastusviranomaisella (palomestari Tommi Antikainen).

Laadittua suunnitelmaa on testattu ja täydennetty paloasemalla järjestetyllä alkusammutuskoulutuksella sekä pelastusharjoituksella, joka järjestettiin Hingunniemen opetusmaatilan ratsutallilla. Alkusammutuskoulutuksen pitivät palo- ja pelastusviranomaiset ja se kohdistettiin oppilaitoksen ensimmäisen vuosikurssin opiskelijoille sekä henkilökunnasta niille, joilta koulutus vielä puuttui. Harjoituksessa talliin lavastettiin tulipalo ja hevoset evakuoitiin mm. käyttäen normaalista poikkeavia ulosmenoreittejä.

\section{Tulokset ja tulosten tarkastelu}

\section{Pelastussuunnitelma}

Pelastussuunnitelma on yhtenäinen turvallisuusasiakirja, joka sisältää pelastus- ja turvallisuussuunnitelmassa tarvittavat asiat. Case-tutkimuksena tehtyä suunnitelmaa voidaan käyttää hyödyksi uusien työntekijöiden perehdyttämisessä sekä opiskelijoiden ja henkilökunnan turvallisuuskoulutuksissa Ylä-Savon ammattiopiston Hingunnimen opetusmaatilan talleilla. Suunnitelma on rajattu pelkästään tallirakennuksiin ja maneesiin sekä niiden välittömään ympäristöön. Suunnitelma sisältää seuraavat asiat:

1 Tilan yleistiedot

1.1 Tärkeitä puhelinnumeroita

1.2 Rakennusten tiedot

1.3 Rakennusten paloluokat

2 Vaaratilanteet, niiden vaikutukset ja toimenpiteet vaaratilanteiden ennaltaehkäisemiseksi

2.1 Sairastapaukset

2.2 Tulipalo

2.3 Kaasuvaara

2.4 Vaaralliset kemikaalit

2.5 Muut toimintaan liittyvät vaaratilanteet

3 Rakenteellinen suojelu

3.1 Rakenteellinen palontorjunta

3.2 Väestönsuojelu

4 Hälytys- ja sammutusjärjestelyt sekä suojelumateriaali

5 Kiinteistön huolto ja vikailmoitukset

6 Työpaikkasuojelu

7 Toimenpiteet onnettomuustapauksissa

8 Liittyminen kunnan pelastuspalveluun ja väestönsuojeluun

9 Lisätiedot

LIITTEET

Liite 1 Yleisohje turvajärjestelyistä

Liite 2 Hätäilmoitus

Liite 3 Toiminta tulipalossa

Liite 4 Sammuttimen käyttö

Liite 5 Palontorjuntaohje

Liite 6 Työpaikan paloturvallisuus

Liite 7 Tallin henkilökunnan tehtävät

Liite 8 Hevosten pelastaminen tulipalosta

Liite 9 Tilan tarkastuslista

Liite 10 Kartta alueesta sekä ratsutallin, ravitallin, pihaton, vierastallin ja maneesin kaaviot

Suunnitelman ensimmäinen luku käsittelee tilan yleistietoja ja arvioidun palokunnan saapumisajan kohteeseen. Lisäksi siitä selviää tärkeitä puhelinnumeroita, tallilla päivystävien tallimestareiden, eläinlääkäreiden sekä kiinteistönhoitajan päivystysnumerot. Rakennusten, eli Hingunniemessä opetusmaatilan ratsutallin, ravitallin, pihaton, vierastallin sekä maneesin, tekniset tiedot: rakennusvuosi, eläinmäärä, kerrosten lukumäärä ja pinta-ala. Myös käyttötavat ja paloluokat on lueteltu. Case-tallilla jokainen rakennus kuului palo- 
luokkaan P3 ja tiloja osastoivien rakenteiden paloluokka oli EI30. Edellämainitut paloluokat kuvaavat, millainen palonkestävyys kantavilla rakenteilla tulipalossa on. Mainitut paloluokat ovat vähimmäisvaatimuksia useimmille eläinsuojille.

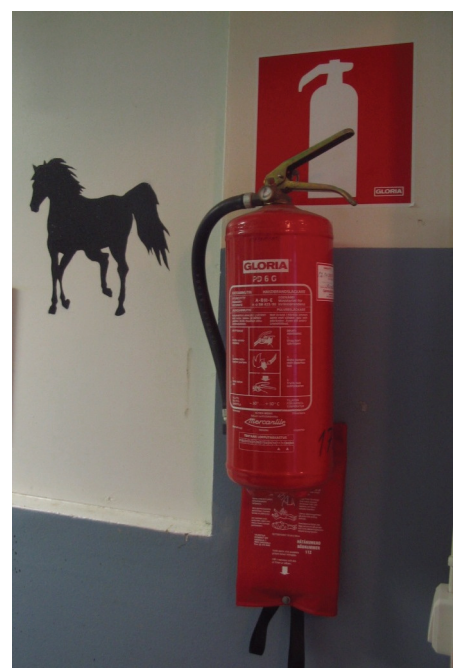

Kuva 2. Oikein merkitty tallin nestesammutin.

Toisessa luvussa eritellään erilaisia mahdollisia onnettomuustilanteita. Niitä ovat esimerkiksi sairastapaukset, tulipalo, kaasuvaara sekä vaarallisten kemikaalien vapautuminen ympäristöön. Jokaisesta esimerkistä kerrotaan niiden vaikutukset, toimenpiteet onnettomuuden sattuessa sekä ennalta-ehkäisevät toimet. Erityiset riskikohteet on kartoitettu ja kerrottu, kuinka ne tulee huomioida. Suunnitelmaan on kuvailtu ja valokuvattu esimerkiksi ensiapukohteiden, palohälyttimien ja alkusammuttimien sijainti eri rakennuksissa (kuva1). Lisäksi on koottu yleisiä huomioita palo-turvallisuudesta ja mietitty toimintaohjeita paloturvallisuutta uhkaavien tilanteiden varalle.

Suunnitelman kolmannessa luvussa keskitytään rakenteelliseen suojeluun, johon kuuluvat rakenteellinen palontorjunta sekä väestönsuojelu. Jokaisesta tallista käydään läpi ilmastointikoneiden hätäpysäytyksen, sähköpääkeskusten sekä veden pääsulkujen sijainti. Ne on myös valokuvattu selkeyden vuoksi. Lisäksi on kerrottu tallien turva- ja merkkivalaistuksesta, poistumisjärjestelyistä sekä väestönsuojan käyttämisestä.

Hälytys- ja sammutinjärjestelyistä kerrotaan luvussa neljä. Siinä on kuvattu, kuinka toimitaan sisäisen tai ulkoisen hälytyksen sattuessa sekä kerrottu automaattisen paloilmoitinjärjestelmän toiminnasta, mahdollisesta automaattisesta sammutuslaitteistosta sekä savunpoistosta. Alkusammutuskaluston ja käsisammuttimien huollon suorittaja sekä väestönsuojelu-materiaalin huoltaja löytyvät luvun lopusta. Tarvittaessa tekstissä on viittauksia myös pelastussuunnitelman lopussa oleviin liitteisiin.

Luvussa viisi listataan ne tahot, joihin voi ottaa yhteyttä kiinteistönhuoltoa, sähkökatkosta, vesihuoltoa, ilmanvaihtolaitteita, tulitöitä ja vakuutusasioita koskevissa asioissa. Seuraavassa luvussa käsitellään työpaikkasuojelua. Suunnitelma sisältää tiedot työpaikan suojeluhenkilöstöstä ja turvallisuusryhmästä sekä niiden tehtävistä. Lisäksi kerrotaan, kuka vastaa henkilökunnan turvallisuuskoulutussuunnitelman toteuttamisesta ja sisällöstä sekä tietoa työpaikan pelastussuunnitelman tarkistamisesta ja jakelusta.

Seitsemännessä luvussa opastetaan, mistä löytyy tarkempia lisätietoja tulipalon sekä kaasu- ja säteilyvaaratilanteen varalle. Kahdeksas luku kertoo, mitkä tahot kunnan osalta vastaavat pelastuspalvelusta ja väestönsuojelusta niin normaali- kuin poikkeusoloissakin. Viimeiseen lukuun on kerätty mm. lähimmän paloaseman ja poliisilaitoksen yhteystietoja sekä muita tärkeitä puhelinnumeroita. Lopuksi on nimilista, joka jokaisen, jonka tulee olla tietoinen pelastussuunnitelman sisällöstä, on kuitattava. Kuittauksella todistetaan, että henkilö on tutustunut suunnitelmaan ja on tietoinen omasta vastuustaan.

Pelastussuunnitelman lopussa on liitteitä, jotka sopivat ulkomuotonsa puolesta esimerkiksi tallin seinälle näkyviin. Liitteet ovat

1. Yleisohje turvajärjestelyistä, joka kertoo mitä tulee ottaa huomioon, jotta onnettomuuksia voidaan ennaltaehkäistä, sekä mitä tulee tehdä, jos onnettomuus silti tapahtuu.

2. Pohjois-Savon pelastuslaitoksen ohje hätäpuhelun soittamiseen

3. Pohjois-Savon pelastuslaitoksen toimintaohjeet tulipaloon.

4. Kuvat ja käyttöohjeet neste- ja hiilidioksidisammuttimelle

5. Palontorjuntaohjeet, joissa on huomioita poistumisteistä, ilmanvaihtohormeista, palo-ovista, alkusammutuskalustosta sekä avotulenteosta ja tupakoinnista.

6. Paloturvallisuutta edistävä muistilista työpaikalta lähdön yhteyteen

7. Henkilökunnan tehtävät, jotka liittyvät alkusammutusvälineiden tarkistukseen ja niiden käytön opettamiseen, tulitöiden valvontaan, varapoistumisteiden tarkistukseen, siisteydestä huolehtimiseen ja paloovien sulkemiseen sekä työpaikan turvallisuusjohtajan tehtävät.

8. Tallimestarin yksityiskohtaisesti kokoamat toimintaohjeet hevosten pelastamisesta ja käsittelemisestä tulipalon tai radioaktiivisen laskeuman uhatessa.

9. Tilan tarkastuslista erilaisista huolto- tai testaustoimenpiteistä sekä niiden ajankohdat

10. Alueen kartta ja jokaisen tallin sekä maneesin kaaviot

11. Ohjapiirrokset, joihin on merkitty rakennusten poistumisreitit ihmisille ja hevosille, sekä alkusammuttimien, ensiapupisteiden, ilmastoinnin hätä-seis-kytkinten ja vesisulkujen sijainnit.

Nämä kartat löytyvät suurennettuina jokaisen tallin seinältä, missä ne parhaiten palvelevatkin. 


\section{Alkusammutuskoulutus}

Alkusammutuskoulutus järjestettiin osana työn tuotoksia. Sen toteuttamisesta vastasi Pohjois-Savon Pelastuslaitoksen Kiuruveden paloasema. Koulutus järjestettiin Ylä-Savon ammattiopiston Hingunniemen yksikön ensimmäisen vuosikurssin opiskelijoille sekä henkilökunnasta niille, joilta alkusammutuskoulutus puuttui. Opetus sisälsi palomestari Tommi Antikaisen paloturvallisuusluennon, demonstraation rasvapalon sammuttamisesta vedellä sekä käytännön harjoittelua kolmessa eri pisteessä. Opetuksesta huolehtivat palomiehet.

Ensimmäisellä pisteellä esiteltiin pikapalopostia ja sankoruiskua sekä niiden käyttöä, toisella rasvapaloa sekä sammutuspeitettä ja kolmannella nestesammuttimen käyttöä. Kaikki pääsivät itse kokeilemaan, kuinka rasvapalo kattilassa sammutetaan turvallisesti patakintaan ja kattilankannen avulla ja kuinka palava henkilö pelastetaan sammutuspeitteen avulla. Harjoituksessa käytettiin nukkea, jonka haalarin rintataskussa oleva öljyinen rätti sytytettiin palamaan. Palomies Pauli Jääskeläinen näytti myös, kuinka rasvapalon saa sammutettua sammutuspeitteellä. Käsisammuttimen käyttöä harjoiteltiin nestesammuttimilla, jotka oli kustannussyistä täytetty vedellä. Altaassa olevat liekit piti saada sen avulla tukahtumaan. (Kuvat 3 ja 4.)

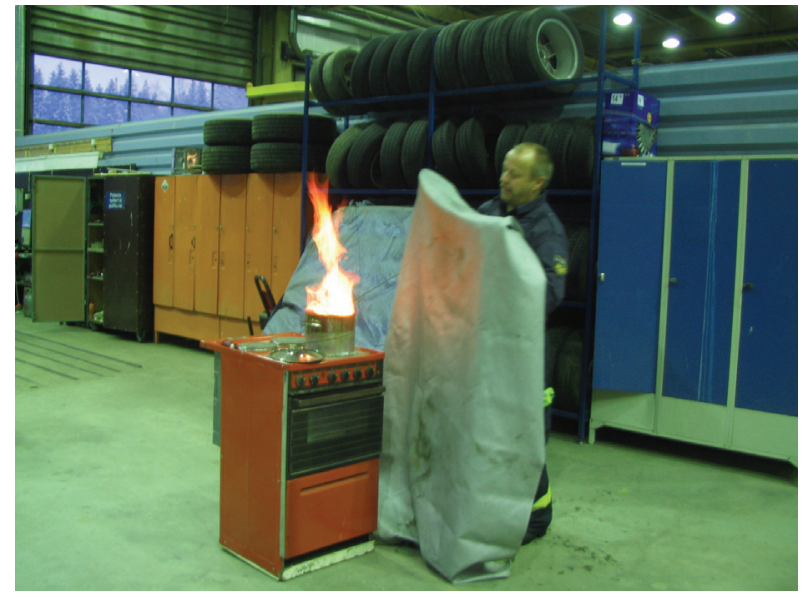

Kuva 3. Palomies Pauli Jääskeläinen näyttää mallia rasvapalon sammuttamiseen.

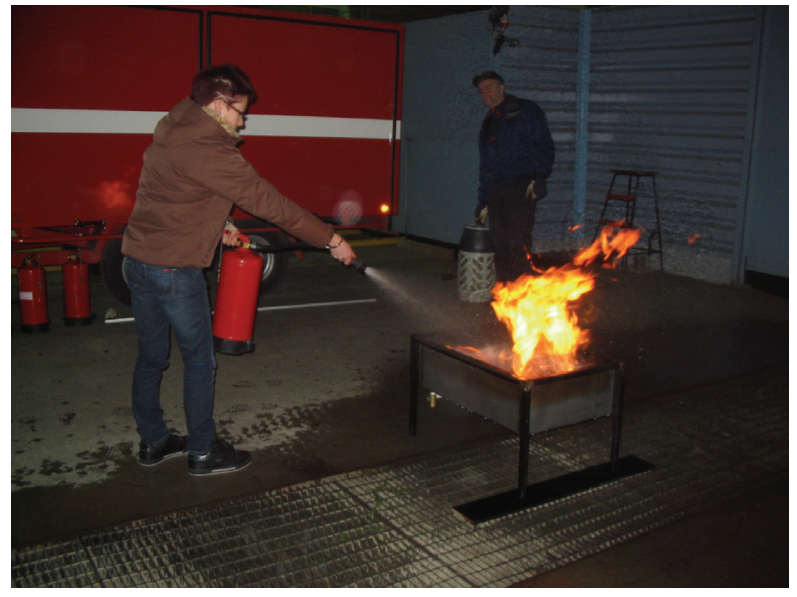

Kuva 4. Hingunniemessä opiskeleva Maikki Vuorela hallitsi nestesammuttimen käytön.

\section{Pelastusharjoituspäivä}

Pelastusharjoituspäivä järjestettiin Hingunniemen opetusmaatilalla toisen ja kolmannen vuoden opiskelijoille sekä tallihenkilökunnalle. Palomestari Tommi Antikaisen turvallisuusluento alusti harjoitusta, jonka vaiheet käytiin etukäteen yhdessä läpi. Ratsutallin oleellisimpaan palon syttymispaikkaan, eli heinälatoon lavastettiin tulipalo altaassa palavan nesteen sekä savukoneen avulla.

Opiskelijat olivat suorittavinaan rutiinitöitä tallivuorollaan, kun palo huomattiin. He ilmoittivat asiasta välittömästi tallimestarille, joka laukaisi palohälyttimen ja jakoi toimintaohjeet opiskelijoille sekä sammutti palon lähimmällä nestesammuttimella. Sillä välin opiskelijat olivat tarkistaneet, olivatko kaikki ihmiset turvassa, ja aloittivat hevosten evakuoimisen. He toivat hevoset ulos eläinten hätäuloskäyntiä käyttäen, eli pääovista. Normaalisti ne ovat tarkoitettu vain ihmisille, mutta niitä käytettiin nyt, sillä palopesäke sijaitsi hevosten yleisellä poistumisreitillä.

Talliin päästettiin yleisen ohjeistuksen mukaisesti vain täysi-ikäiset opiskelijat. Alaikäiset opiskelijat odottivat pihalla, sillä tositilanteessa heitä ei saa velvoittaa vaarallisiin pelastustöihin. He kuljettivat rauhallisesti pihalle tuodut hevoset lähimpiin ulkoilutarhoihin, jotka toimivat eläinten kokoamispaikkana. Alueelle saapuva pelastusyksikkö piti opastaa tapahtumapaikalle ja kertoa, mitä oli tapahtunut. Myös paikalla olleiden henkilöiden piti kokoontua yhteen ja varmistaa, että kaikki olivat paikalla. Turvallisuuden vuoksi harjoituksesta oli jätetty pois nuoret hevoset sekä oriit, Hingunniemen ja Pelastuslaitoksen henkilökunta valvoi tapahtumia kaiken aikaa.

Harjoitus toteutettiin kaksi kertaa peräkkäin, jotta kaikki opiskelijat ja hevoset pääsivät harjoittelemaan. Ne henkilöt, jotka eivät osallistuneet tapahtumiin, havainnoivat harjoituksen kulkua ja arvioivat sen sujuvuutta. Huomattiin, että vaikka savu oli vaaratonta teatterisavua ja sitä ei missään vaiheessa johdettu tallin puolelle, osa hevosista reagoi siihen erittäin voimakkaasti. Myös palohälytyksen laukaisemisen aikaan- 
saama palokellon soiminen hermostutti eläimiä. Erilaisen uloskäynnin käyttäminen pelotti osaa hevosista, mutta rauhallisempaa hevosta seuraamalla nekin saatiin turvallisesti rakennuksesta ulos. Osa hevosista oli jo päässyt aikaisemmin harjoittelemaan hätäuloskäynnistä poistumista, joten sillä huomattiin olevan vaikutusta. Taluttajan varma ja rauhallinen käytös oli kuitenkin kaikista tärkeintä. Palomestari Antikainen korosti, että hätätilanteessakaan ja varsinkin hevosta käsiteltäessä ei saa koskaan juosta. (Kuvat 5 ja 6.)

Harjoitus herätti paljon keskustelua ja mielipiteitä, ja yleisesti ottaen sen katsottiin onnistuneen erittäin hyvin. Opiskelijat saivat palautetta $\mathrm{mm}$. siitä, että pelastusyksikön saavuttua paikalle kaikkien on oltava selkeästi koossa, jotta tiedetään, onko ketään jäänyt vaaraan. Myös tallimestarin ohjeita tulisi kuunnella onnettomuustilanteessa tarkasti, eikä saa toimia omin päin. Pelastusharjoituspäivä poiki myös jatkokoulutusidean, sillä myöhemmin Kiuruveden palokunta kävi harjoittelemassa Hingunniemessä hevosten käsittelyä.

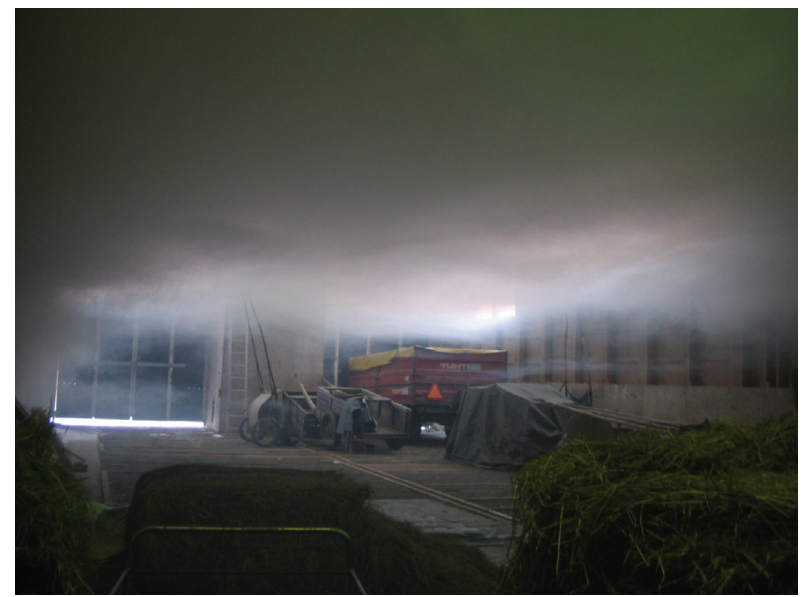

Kuva 5. Heinälato täyttyi teatterisavusta puolilleen.

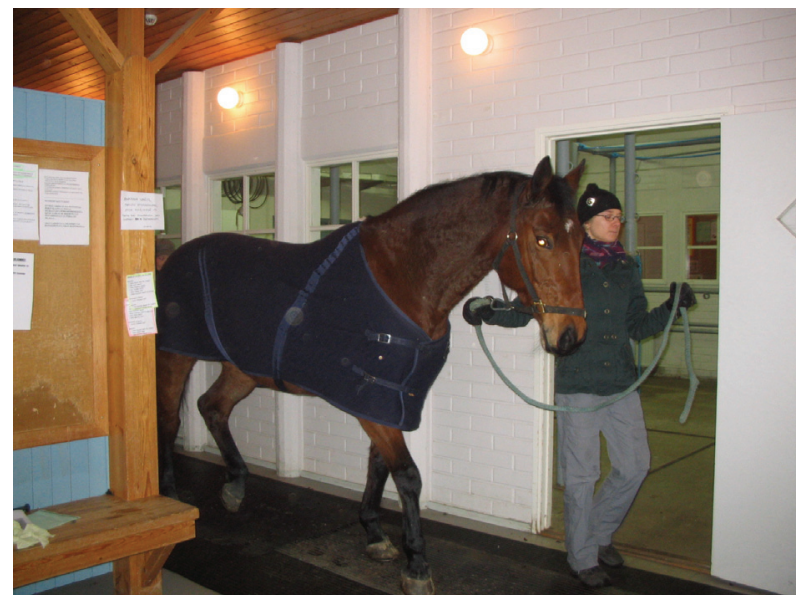

Kuva 6. Jenni Päätalo taluttaa Gildan rauhallisesti eteisaulan läpi ulos.

\section{Johtopäätökset}

Turvallisuussuunnittelu ja -koulutus eivät koskaan mene hukkaan. Pelastussuunnitelman tarkoituksena on parantaa tallien turvallisuutta auttamalla toimijoita huomioimaan riskejä ja sitä kautta ennaltaehkäisemään onnettomuuksia. Alkusammutustaidot ja muu turvallisuuskoulutus puolestaan ovat takeena siitä, että onnettomuuden sattuessa paikalla olevat henkilöt osaavat minimoida sen vahingot ja seuraukset.

Pelastussuunnitelman luotettavuuden varmistaa se, että se on paloviranomaisen tarkastama ja otettu käyttöön cese-talleilla. Suunnitelmaa tulee kehittää systemaattisesti ja oleellista on, että se syntyy todellisesta tarpeesta. Käyttöönoton jälkeen pelastussuunnitelmaa tulee päivittää vuosittain ja tiedottaa sen sisällöstä uusille työntekijöille. Näin sen tiedot eivät pääse vanhenemaan, vaan se pysyy kaiken aikaa käyttökelpoisena.

Suunnitelma on yhtenäinen perehdyttämisoppaana toimiva tietopaketti. Turhaa toistamista välttämällä ja kuvia lisäämällä lopputulos on helppolukuinen ja selkeä. Vuosittainen turvallisuuskoulutus parantaa selvästi toimijoiden, case-tallilla opiskelijoiden ja henkilökunnan, varmuutta onnettomuustilanteessa toimimisesta. Hevoset voivat vauhkoontua tulipalon havaitessaan, ja niiden käytös mahdollisesti rauhoittuu, kun niiden kanssa on etukäteen harjoiteltu pelottavia tilanteita.

Hyvin laaditut turvallisuusohjeet työntekijöiden ja asiakkaiden näkyvillä parantavat myös tallin imagoa. Pelastussuunnitelma pitää ajan tasalla, jotta siitä saadaan täysi hyöty. Ylä-Savon ammattiopiston Hingunniemen opetusmaatilan hevostalleille laadittu pelastussuunnitelma on esillä Virtuaalikylän Internet-sivuilla www.virtuaali.info, missä esitellään Suomessa toimivien luonnonvara-alan ammattiopistojen koulutiloja ja niiden toimintaa. 


\section{Kirjallisuus}

Granqvist, P., Nurmi, V-P. \& Nenonen, A. 2006. Eläintilojen sähkö- ja paloturvallisuus. TUKES-julkaisu 2/2006. Helsinki: Turvatekniikan keskus.

Majamaa, J. 2008. Maatilan paloturvallisuus - suunnittelijan opas. Suomen Pelastusalan Keskusjärjestö SPEK 21. Tampere: Tammer-Paino Oy.

Pesonen, I., Virtanen, H. \& Jansson, H. (toim.) 2008. Hyvinvoiva, turvallinen ja ympäristöystävällinen talli - opas vastuulliseen tallitoimintaan. Agropolis Oy. Forssa: Painotalo Auranen Oy.

Piminäinen, K. 2005. Hevoset ja työturvallisuus - turvallinen työskentely hevosen kanssa. 2. painos. Työturvallisuuskeskus. IS-Print.

Ammattitautiasetus. (N:o 1347/1988). Finlex. Lainsäädäntö. [Viitattu 17.11.2008] Saatavissa: http://www.finlex.fi/fi/laki/ajantasa/1988/19881347?search[type]=pika\&search[pika]=ammattitautiasetus

Aalto, Arja. 2008. Hingunniemen vastaava tallimestari. Henkilökohtainen tiedonanto 11.12.2008. Ylä-Savon ammattiopisto, Kiuruvesi.

Antikainen, Tommi. 2009. Palomestari. Luento 11.12.2008. Pohjois-Savon pelastuslaitos, Kiuruvesi.

Kuluttajavirasto - palvelun tarjoajan turvallisuusasiakirja. [Viitattu 21.9.2008] Saatavissa:

http:/www.kuluttajavirasto.fi/Page/5e645600-7184-4f05-87c8-73ae58d73468.aspx

Laki kulutustavaroiden ja kuluttajapalvelusten turvallisuudesta. (N:o 75/2004) Finlex. [Viitattu 24.11.2008] Saatavissa: http://www.finlex.fi/fi/laki/ajantasa/2004/20040075

Laki nuorista työntekijöistä. (N:o 475/2006) Finlex. [Viitattu 17.11.2008] Saatavissa.

http://www.finlex.fi/fi/laki/ajantasa/2006/20060475? search[type]=pika\&search[pika]=508\%2F198

Laki työsuojelun valvonnasta ja työpaikan työsuojeluyhteistoiminnasta. (N:o 44/2006) Finlex. [Viitattu

10.11.2008] Saatavissa: http://www.finlex.fi/fi/laki/ajantasa/2006/20060044

Maankäyttö- ja rakennuslaki. (N:o 132/1999) Finlex. [Viitattu 24.11.2008] Saatavissa:

http://www.finlex.fi/fi/laki/ajantasa/1999/19990132?search[type]=pika\&search[pika]=Maank\%C3\%A4ytt\%C3\%B6$\% 20 \mathrm{ja} \% 20$ rakennuslaki

MMM:n asetus tuettavaa rakentamista koskevista paloteknisistä vaatimuksista. (N:o 25/2005) Finlex. [Viitattu10.11.2008] Saatavissa: http://www.finlex.fi/pdf/normit/18836-04025fi.pdf

Paavola, T. 2006. Turvallisuus on suunnittelemisen arvoista -artikkeli. [Viitattu 23.7.2008] Saatavissa:

www.bluegate.fi/Kuvat/Hippos.pdf

Palotarkastusohje. 2001. Julkaisu. [Viitattu 24.7.2008] Saatavissa: http://www.finlex.fi/data/normit/24739-

palotark.pdf

Pelastuslaki. (N:o 468/2005) Finlex. [Viitattu 21.9.2008] Saatavissa:

http://www.finlex.fi/fi/laki/ajantasa/2003/20030468?search[type]=pika\&search[pika]=pelastussuunnitelma

Pelastustoimi, neuvontapalvelu. [Viitattu 23.7.2008] Saatavissa:

http://www.pelastustoimi.fi/neuvontapalvelu/2599?keyword=pelastussuunnitelma\#firstHit

SRL. Turvallinen ratsastusseuratoiminta. [Viitattu 23.7.2008] Saatavissa:

http://www.ratsastus.fi/asp/system/empty.asp?P=760\&VID=default\&SID=188328516242267\&S=1\&C=25811

Terveydensuojelulaki. (N:o 763/1994) Finlex. [Viitattu 10.11.2008] Saatavissa:

http://www.finlex.fi/fi/laki/ajantasa/1994/19940763?search[type]=pika\&search[pika]=terveydensuojelulaki

Turvallisuussuunnitelma. 2007. Ylä-Savon ammattiopiston turvallisuussuunnitelma, sis. Hevostalous - Hingunniemi ja Museokadun asuntolat + liitteet.

Työterveyshuoltolaki. (N:o 1383/2001) Finlex. [Viitattu 17.11.2008] Saatavissa:

http://www.finlex.fi/fi/laki/ajantasa/2001/20011383?search[type]=pika\&search[pika]=Ty\%C3\%B6terveyshuoltolaki

Työturvallisuuslaki. (N:o 738/2002) Finlex. [Viitattu 10.11.2008] Saatavissa:

http://www.finlex.fi/fi/laki/ajantasa/2002/20020738?search[type]=pika\&search[pika]=ty\%C3\%B6turvallisuuslaki\%207 $\underline{38}$

Valtioneuvoston asetus nuorille työntekijöille erityisen haitallisista ja vaarallisista töistä. (N:o 475/2006) Finlex. Lainsäädäntö. [Viitattu 17.11.2008] Saatavissa:

http://www.finlex.fi/fi/laki/ajantasa/2006/20060475?search[type]=pika\&search[pika]=508\%2F1986

Valtioneuvoston asetus työpaikkojen turvallisuus- ja terveysvaatimuksista. (N:o 577/2003) Finlex. Lainsäädäntö. [Viitattu 10.11.2008] Saatavissa: http://www.finlex.fi/fi/laki/ajantasa/2003/20030577

Kuvat: Milka Taivassalo 2009 